\title{
BMJ Asthma and allergies in Jamaican Open children aged 2-17 years: a cross-sectional prevalence survey
}

\author{
Eulalia K Kahwa, ${ }^{1}$ Norman K Waldron, ${ }^{1}$ Novie O Younger, ${ }^{2}$ \\ Nancy C Edwards, ${ }^{3}$ Jennifer M Knight-Madden, ${ }^{2}$ Kay A Bailey, ${ }^{4}$ Yvonne B Wint, ${ }^{1}$ \\ Karen N Lewis-Bell ${ }^{5}$
}

To cite: Kahwa EK, Waldron NK, Younger NO, et al. Asthma and allergies in Jamaican children aged 2-17 years:

a cross-sectional prevalence survey. BMJ Open 2012;2: e001132. doi:10.1136/ bmjopen-2012-001132

- Prepublication history for this paper is available online. To view these files please visit the journal online (http://dx.doi.org/10.1136/ bmjopen-2012-001132).

Received 9 March 2012 Accepted 6 June 2012

This final article is available for use under the terms of the Creative Commons Attribution Non-Commercial

${ }^{1}$ The UWI School of Nursing, Mona, University of the West Indies, Kingston, Jamaica

${ }^{2}$ Tropical Metabolism

Research Institute, University of the West Indies, Kingston, Jamaica

${ }^{3}$ School of Nursing, Department of Epidemiology and Community Medicine, University of Ottawa, Ottawa, Ontario, Canada

${ }^{4}$ Department of Obstetrics, Gynaecology and Child Health, University of the West Indies, Kingston, Jamaica

${ }^{5}$ Department of Family Health, Ministry of Health, Kingston, Jamaica

Correspondence to

Dr Eulalia Kokuangisa Kahwa; eulalia.kahwa02@uwimona. edu.jm

\section{ABSTRACT}

Objective: To determine the prevalence and severity of asthma and allergies as well as risk factors for asthma among Jamaican children aged 2-17 years.

Design: A cross-sectional, community-based prevalence survey using the International Study of Asthma and Allergies in Childhood questionnaire. The authors selected a representative sample of 2017 children using stratified, multistage cluster sampling design using enumeration districts as primary sampling units.

Setting: Jamaica, a Caribbean island with a total population of approximately 2.6 million, geographically divided into 14 parishes.

Participants: Children aged 2-17 years, who were resident in private households. Institutionalised children such as those in boarding schools and hospitals were excluded from the survey.

Primary and secondary outcome measures: The prevalence and severity of asthma and allergy symptoms, doctor-diagnosed asthma and risk factors for asthma.

Results: Almost a fifth (19.6\%) of Jamaican children aged 2-17 years had current wheeze, while $16.7 \%$ had self-reported doctor-diagnosed asthma. Both were more common among males than among females. The prevalence of rhinitis, hay fever and eczema among children was $24.5 \%, 25 \%$ and $17.3 \%$, respectively. Current wheeze was more common among children with rhinitis in the last 12 months $(44.3 \%$ vs $12.6 \%$, $p<0.001)$, hay fever $(36.8 \%$ vs $13.8 \%, p<0.001)$ and eczema (34.1\% vs $16.4 \%, p<0.001)$. Independent risk factors for current wheeze (ORs, $95 \% \mathrm{Cl}$ ) were chest infections in the first year of life 4.83 (3.00 to 7.77), parental asthma 4.19 (2.8 to 6.08), rhinitis in the last 12 months 6.92 (5.16 to 9.29), hay fever 4.82 (3.62 to 6.41), moulds in the home 2.25 (1.16 to 4.45 ), cat in the home 2.44 (1.66 to 3.58 ) and dog in the home 1.81 (1.18 to 2.78 ).

Conclusions: The prevalence of asthma and allergies in Jamaican children is high. Significant risk factors for asthma include chest infections in the first year of life, a history of asthma in the family, allergies, moulds and pets in the home.

\section{ARTICLE SUMMARY}

\section{Article focus}

- The prevalence of asthma and allergies in both developed and developing countries is continuing to rise.

- In some Caribbean countries, asthma is a public health problem associated with high economic costs.

- This study determined the prevalence of asthma, allergy symptoms and associated risk factors.

\section{Key messages}

- We demonstrated that the prevalence of asthma and allergy symptoms among Jamaican children aged 2-17 years is high.

- Both the prevalence and severity of asthma symptoms are comparable to that reported among children in high-income countries.

- Current wheeze and doctor-diagnosed asthma were more common in males and in children with allergies.

- A history of asthma in the family, chest infections in the first year of life, allergies, exposure to moulds and pets in the home were associated with significant risk for asthma.

- Identifying children at high risk for asthma and controlling modifiable risk factors is important in reducing the prevalence and morbidity related to asthma.

Strengths and limitations of this study

- This is the first national study on asthma and allergies in Jamaica using a nationally representative sample of children with a response rate of $80 \%$.

- We used a modified ISAAC protocol in which sampling was done by household rather than by school. Using a population-based sampling strategy; we sampled one child and one adult per household. This approach enabled us to obtain national prevalence estimates for both adults and children in one survey at a reduced cost.

- Limitations of this study include the fact that the prevalence of asthma and allergies was based solely on self-reports, no objective measures were done. Also in younger children, caregivers responded to questionnaires. 


\section{INTRODUCTION}

Epidemiological studies examining asthma prevalence trends among children in both developed and developing countries suggest that the prevalence of asthma and other allergic diseases is continuing to rise. ${ }^{1}$ The International Study of Asthma and Allergies in Childhood phase 3 (ISAAC) indicated an increase in asthma symptoms in Latin America, Africa and parts of Asia over a 5-10-year period. ${ }^{1}$ While the prevalence of asthma and other allergic disorders in most Caribbean countries is not known, in ISAAC phase 3, the prevalence of current wheeze among Barbadian children aged 6-7 years and 13-14 years was $19.2 \%$ and $20.9 \%$, respectively. ${ }^{1}$ In another study, the prevalence of current wheeze in the 11-19-year age group was $13.1 \%$ in Trinidad and $13.4 \%$ in Tobago. $^{2}$ While causes of the observed increase in asthma prevalence are not clearly understood, current evidence suggests that gene-environment interactions underlie most of the increase and worldwide variations. ${ }^{3}$ Known risk factors for asthma include genetic, lifestyle, environmental factors and demographic variables. ${ }^{3}$

In Jamaica, current data on the prevalence of asthma, allergies and risk factors associated with these diseases are lacking. The most recent asthma prevalence estimates were from a small clinical cohort of children aged 5-10 years using a modified ISAAC questionnaire, which reported $48 \%$ asthma prevalence among children with sickle cell disease and $22 \%$ among ethnic-matched controls. ${ }^{4}$ A larger school-based study reported an asthma prevalence of $21 \%$ among high school children. However, this study was conducted in 1981 using a non-standardised questionnaire. ${ }^{5}$ The objectives of this national survey were (1) to determine the prevalence and severity of asthma and allergy symptoms among Jamaican children aged 2-17 years and (2) to determine risk factors for asthma in children. Current asthma and allergy prevalence data are critical for healthcare planning. Identifying modifiable risk factors for asthma may inform strategies for primary prevention and management.

\section{METHODS}

\section{Study design}

A nation wide, cross-sectional, community-based prevalence survey. Methods used in the survey have been described in detail elsewhere. ${ }^{6}$

\section{Setting}

Jamaica is a Caribbean island with a total population of approximately 2.6 million. The country is geographically divided into 14 parishes consisting of 5235 enumeration districts (EDs) stratified into 2542 urban and 2693 rural EDs. The survey was conducted in all 14 parishes during the period January to March 2007.

\section{Participants}

Two thousand and seventeen children aged 2-17 years participated in the survey. Children younger than 2 years were excluded from the study since conditions such as bronchiolitis and other causes of wheezing and coughing that cannot be differentiated from asthma symptoms are common in this age group. Children were eligible to participate in the study only if they were residents of selected households. Children in institutions such as boarding schools and hospitals were excluded from the study.

Stratified, multistage cluster sampling design using EDs as primary sampling units was done similar to other national surveys. A detailed description of the sampling design is presented elsewhere. ${ }^{6}$ Briefly, in stage 1 , a random sample of EDs was selected proportional to parish size and independently from both urban and rural EDs. Stage 2 involved the selection of households using systematic probability sampling. A total of 3719 households were selected. The Kish selection table ${ }^{7}$ was then used to select one eligible child per household in stage 3 yielding a sample size of 2017 .

\section{Data collection procedures}

The ISAAC phase 2 questionnaire was interviewer administered to caregivers of children younger than 12 years and to children aged 13 years and older in the presence of their caregivers. The questionnaire included items on the presence and severity of asthma and allergy symptoms, doctor-diagnosed asthma, risk factors for asthma, past and present environmental exposures. ${ }^{8}$ Demographic data collected for children include age, sex and race as observed by the interviewer. Questions related to risk factors for asthma were answered by the caregiver. The question asking "has your child ever had asthma" was modified to "has your child ever had asthma or even a touch of asthma?" since the latter term is used in Jamaica to describe cases of mild-to-moderate asthma. ${ }^{4}$ Another question "was asthma diagnosed by the doctor?" was added to the questionnaire. Questionnaires were administered in English.

\section{Data analysis}

Data analysis accounted for sampling design, produced weighted prevalence estimates for asthma and allergy symptoms and doctor-diagnosed asthma with SE estimates adjusted for the multistage sampling design used in the study. Prevalence estimates were obtained for each of the four age categories $(2-4,5-9,10-14$ and $15-17$ years). Separate estimates were obtained for the 6-7-year and 13-14-year age groups to facilitate comparison of results from this study with results from studies that used the ISAAC questionnaire in the 6-7-year and 13-14-year age groups. Sex-specific estimates of prevalence were also obtained within the entire age range (2-17 years) studied, the 6-7-year and 13-14-year age groups and area of residence to determine urban/rural differences in asthma prevalence. In Jamaica, a place is classified as an urban area if it has a population of 2000 or more people and provides a number of amenities and utilities which indicate modern living. ${ }^{9}$ The severity of asthma symptoms 
in the last 12 months was assessed using responses to questions on the number of attacks of wheezing in the last 12 months and wheezing resulting in sleep disturbance or limiting speech to one or two words.

$\chi^{2}$ Tests corrected for variability due to multistage sampling design (Rao-Scott correction yielding Fstatistic) and logistic regression were used to determine the nature of the association between risk factors, asthma and allergy symptoms and demographic variables. Stata V.10.0 was used to carry out data analysis. ${ }^{10}$

Logistic regression models produced ORs indicating associations between 'current wheeze' (wheezing in the last 12 months) and risk factors adjusted for confounders such as age, sex and area of residence. Risk factors included in models were those significantly associated with current wheeze in bivariate analyses.

\section{RESULTS}

A sample of 2017 children aged 2-17 years consisting of 1019 males $(50.6 \%$ of the population of $2-17$-year-olds) and 998 females (49.4\% of the population of 2-17-yearolds) were recruited for the study yielding a response rate of $80 \%$. Most of the children $(64.5 \%)$ were in the 5-14year age group and predominantly black $(94.0 \%)$. Just over half of the sample $(53.6 \%)$ was recruited from rural areas. Demographic characteristics of the sample are shown in table 1 .

\section{The prevalence of asthma symptoms by sex and area of residence}

Prevalence estimates and 95\% CIs for prevalence and severity of asthma and allergy symptoms by sex are shown in table 2. The overall prevalence of current wheeze among children aged 2-17 years was $19.6 \%$ (17.60\% to $21.67 \%)$. Current wheeze and doctor-diagnosed asthma were more common among males than among females.

There were no significant urban/rural differences in the prevalence of current wheeze ( $18.5 \%$ urban, $20.5 \%$

\begin{tabular}{lcc} 
Table 1 & Demographic characteristics of the sample \\
\hline Variables & $\begin{array}{c}\text { Unweighted } \\
\text { sample, } \mathbf{n}(\%)\end{array}$ & $\begin{array}{l}\text { Weighted } \\
\text { sample (\%) }\end{array}$ \\
\hline Age in years & & \\
$2-4$ & $370(18.3)$ & 18.4 \\
$5-9$ & $666(33.0)$ & 33.3 \\
$10-14$ & $639(31.7)$ & 31.2 \\
$15-17$ & $342(16.9)$ & 17.1 \\
Sex & & \\
$\quad$ Male & $1019(50.5)$ & 50.6 \\
$\quad$ Female & $998(49.5)$ & 49.4 \\
Observed race & & \\
$\quad$ African-American & $1893(94.5)$ & 94.0 \\
$\quad$ Mixed & $102(5.1)$ & 5.5 \\
$\quad$ Indian & $7(0.4)$ & 0.5 \\
Area of residence & & \\
$\quad$ Urban & $912(45.2)$ & 46.4 \\
$\quad$ Rural & $1105(54.8)$ & 53.6 \\
\hline
\end{tabular}

rural, $\mathrm{p}=0.31)$ and doctor-diagnosed asthma (18.3\% urban, $15.4 \%$ rural, $\mathrm{p}=0.15$ ).

\section{Age-related differences in the prevalence and severity of asthma symptoms}

The prevalence and severity of asthma symptoms by age is shown in table 3. Children aged 2-4 years had a significantly higher prevalence of current wheeze, 'wheeze ever' and exercise-induced wheeze compared with older age groups and were more likely than older children to have severe asthma symptoms.

The prevalence and severity of allergy symptoms by age, sex and area of residence

The prevalence and severity of allergy symptoms in children aged 2-17 years is also shown in tables 2 and 3 . There were no significant sex-specific differences in the prevalence of allergy symptoms. However, significantly more females than males reported having itchy rash ever' and flexural rash.

There were significant age-related differences in the prevalence of allergy symptoms. The prevalence of rhinitis increased with increasing age (table 3). The 15-17-year age group had the highest prevalence of 'rhinitis ever' (38.7\%), rhinitis in the last 12 months $(32.6 \%)$ and 'hay fever ever' $(40.6 \%)$ compared with younger age groups.

The only difference found in allergy symptoms based on area of residence was the higher prevalence of 'eczema ever' among children in urban compared with those in rural areas (19.9\% urban, $15.1 \%$ rural, $p=0.02$ ).

The prevalence of asthma and allergy symptoms in the 6-7year and 13-14-year age groups

In the 6-7-year age group, the prevalence of current wheeze was $22.4 \%$ and doctor-diagnosed asthma was $20.2 \%$. There were no statistically significant gender differences in the prevalence and severity of asthma symptoms (table 4). Among the 13-14-year-olds, the prevalence of current wheeze was $18.5 \%$ and doctordiagnosed asthma was $19.2 \%$. There were no statistically significant differences between males and females in the prevalence of current wheeze and doctor-diagnosed asthma. However, in this age group, more males (13\%) than females $(3.9 \%, \mathrm{p}=0.02)$ had 4 to 12 wheezing attacks in the last 12 months, suggesting severe asthma.

\section{The prevalence of asthma symptoms among children with allergies}

The prevalence of asthma symptoms was significantly higher in children who had allergies (table 5). More than three times as many children who had "rhinitis in the last 3 months" had current wheeze $(44.3 \%$ vs $14.1 \%, \mathrm{p}<0.001)$ and nocturnal cough $(43.8 \%$ vs $9.7 \%$, $\mathrm{p}<0.001)$. Doctor-diagnosed asthma was also twice as common among children who had rhinitis in the last 12 months $(32.9 \%$ vs $12.0 \%, \mathrm{p}<0.001)$, hay fever $(26.6 \%$ vs $13.3 \%, \mathrm{p}<0.001)$ and eczema $(29.4 \%$ vs $14.0 \%$, $\mathrm{p}<0.001)$ compared with children without allergies. 
Table 2 Weighted prevalence estimates (\%) and $95 \% \mathrm{Cl}$ for asthma and allergy symptoms by sex

\begin{tabular}{|c|c|c|c|c|c|}
\hline & $\begin{array}{l}\text { Male } \\
(n=1019)\end{array}$ & $\begin{array}{l}\text { Female } \\
(n=998)\end{array}$ & $\begin{array}{l}\text { Total } \\
(n=2017)\end{array}$ & $95 \% \mathrm{Cl}$ & p Value \\
\hline \multicolumn{6}{|l|}{ Asthma symptoms } \\
\hline Ever had wheezing & 21.8 & 21.2 & 21.5 & 19.4 to 23.8 & 0.78 \\
\hline Wheezing in the last 12 months & 20.6 & 18.5 & 19.6 & 17.6 to 21.7 & 0.03 \\
\hline \multicolumn{6}{|l|}{ Number of attacks of wheezing in the last 12 months } \\
\hline $1-3$ times & 13.2 & 12.3 & 12.8 & 11.2 to 14.6 & \multirow[t]{3}{*}{0.70} \\
\hline $4-12$ times & 5.9 & 5.1 & 5.5 & 4.4 to 6.8 & \\
\hline$>12$ times & 1.4 & 1.1 & 1.3 & 0.9 to 1.9 & \\
\hline \multicolumn{6}{|l|}{ Sleep disturbance due to wheezing in the last 12 months } \\
\hline$<$ Once/week & 8.9 & 5.5 & 7.2 & 5.9 to 8.8 & \multirow[t]{2}{*}{0.04} \\
\hline >Once/week & 5.0 & 6.3 & 5.6 & 4.5 to 7.0 & \\
\hline Wheezing limited speech to 1 or 2 words & 6.7 & 4.7 & 5.7 & 4.7 to 6.9 & 0.19 \\
\hline Wheezing occurring during or after exercise & 10.2 & 8.7 & 9.4 & 8.0 to 11.0 & 0.47 \\
\hline Asthma ever & 19.5 & 17.0 & 18.2 & 16.2 to 20.4 & 0.16 \\
\hline Asthma diagnosed by a doctor & 17.2 & 16.2 & 16.7 & 14.8 to 18.8 & 0.01 \\
\hline Dry night cough at night unrelated to cold/chest infection & 16.5 & 18.4 & 17.4 & 15.3 to 19.8 & 0.33 \\
\hline \multicolumn{6}{|l|}{ Rhinitis } \\
\hline Rhinitis ever & 23.5 & 25.6 & 24.5 & 22.3 to 27.0 & 0.34 \\
\hline Rhinitis in the last 12 months & 19.3 & 21.3 & 20.3 & 18.1 to 22.6 & 0.59 \\
\hline Burning, itchy, watery eyes & 13.3 & 14.3 & 13.8 & 12.0 to 15.8 & 0.59 \\
\hline \multicolumn{6}{|l|}{ Rhinitis affected daily activities } \\
\hline Not at all & 9.2 & 10.1 & 9.6 & 8.1 to 11.4 & \multirow[t]{4}{*}{0.85} \\
\hline A little & 6.8 & 7.8 & 7.3 & 6.1 to 8.7 & \\
\hline Moderate & 1.5 & 1.7 & 1.6 & 1.1 to 2.5 & \\
\hline A lot & 1.3 & 1.5 & 1.4 & 1.0 to 2.1 & \\
\hline Ever had hay fever & 24.3 & 25.7 & 25.0 & 22.5 to 27.7 & 0.57 \\
\hline \multicolumn{6}{|l|}{ Eczema } \\
\hline Itchy rash ever & 14.2 & 18.4 & 16.3 & 14.4 to 18.3 & 0.01 \\
\hline Flexural rash & 10.5 & 14.0 & 12.2 & 10.5 to 14.0 & 0.03 \\
\hline \multicolumn{6}{|l|}{ Child awakened by itchy rash in the last 12 months } \\
\hline Not at all & 89.3 & 85.7 & 87.5 & 85.6 to 89.1 & \multirow[t]{3}{*}{0.19} \\
\hline$<$ Once/week & 2.9 & 3.3 & 3.1 & 2.4 to 4.1 & \\
\hline >Once/week & 2.1 & 2.7 & 2.4 & 1.8 to 3.3 & \\
\hline Rash cleared completely & 8.3 & 11.9 & 10.0 & 8.7 to 11.6 & 0.05 \\
\hline Eczema ever & 16.4 & 18.3 & 17.3 & 15.4 to 19.5 & 0.33 \\
\hline
\end{tabular}

Risk factors for asthma among Jamaican children

Unadjusted ORs and 95\% CI associated with risk factors for current wheeze are shown in table 6 . In bivariate analysis, significant risk factors for current wheeze were chest infections in the first year of life, maternal and paternal asthma, allergies, moulds and the presence of pets in the home currently and in the first year of life. Table 7 shows ORs resulting from multiple regression analysis adjusted for age, sex and area of residence in which chest infections in the first year of life, parental asthma, allergies, the presence of pets and moulds in the home retained statistical significance.

\section{DISCUSSION}

In this prevalence survey, almost a fifth $(19.6 \%)$ of Jamaican children aged 2-17 years had current wheeze, while $16.7 \%$ had self-reported doctor-diagnosed asthma. Both were more common among males than among females. Almost $6 \%$ (5.5\%) of children had severe asthma.
The prevalence of rhinitis, hay fever and eczema among children was $24.5 \%, 25 \%$ and $17.3 \%$, respectively. Current wheeze was more common among children with rhinitis in the last 12 months, hay fever and eczema. Significant risk factors for asthma were chest infections in the first year of life, parental asthma, rhinitis in the last 12 months, hay fever, moulds as well as cats and dogs in the home.

To our knowledge, this is the first population-based study of asthma and allergy symptoms among Jamaican children. We have shown that the prevalence of asthma is high and comparable to the high prevalence ranging between $15 \%$ and $20 \%$ reported in high-income countries. ${ }^{1}$ Within the Caribbean, the prevalence of asthma in Jamaican children is similar to that observed among Barbadian children aged 6-7 and 13-14 years but differs from the lower prevalence observed in the 11-19-yearsolds in Trinidad and Tobago. ${ }^{1}{ }^{2}$ While the differences in prevalence may in part be due to differences in the age studied, variations in asthma prevalence from country to country and within countries have been reported. ${ }^{1}$ 
Table 3 Weighted prevalence estimates (\%) and severity of asthma and allergy symptoms by age

Age in years

$2-4(n=370) \quad 5-9(n=666) \quad 10-14(n=639) \quad 15-17(n=342)$

Total $(n=2017)$

p Value

Asthma symptoms

\begin{tabular}{|c|c|c|c|c|c|c|}
\hline & & & & & & \\
\hline Wheezing ever & 29.2 & 22.0 & 18.7 & 17.2 & 21.5 & 0.001 \\
\hline $\begin{array}{l}\text { Wheezing in the last } \\
12 \text { months }\end{array}$ & 27.8 & 20.2 & 16.6 & 14.9 & 19.6 & 0.002 \\
\hline \multicolumn{7}{|c|}{ Number of wheezing attacks in the last 12 months } \\
\hline $1-3$ times & 18.3 & 12.8 & 10.5 & 10.8 & 12.8 & 0.004 \\
\hline $4-12$ times & 8.2 & 6.0 & 4.9 & 2.6 & 5.5 & \\
\hline$>12$ times & 1.3 & 1.3 & 1.2 & 1.4 & 1.3 & \\
\hline \multicolumn{7}{|c|}{ Sleep disturbance due to wheezing in the last 12 months } \\
\hline$\leq 1$ night/week & 8.5 & 8.4 & 6.6 & 4.5 & 7.2 & 0.002 \\
\hline$>1$ night/week & 9.3 & 5.9 & 4.3 & 3.5 & 5.6 & \\
\hline $\begin{array}{l}\text { Wheezing limited speech to } \\
1 \text { or } 2 \text { words }\end{array}$ & 3.9 & 6.9 & 5.7 & 5.4 & 5.7 & 0.001 \\
\hline Asthma ever & 19.1 & 20.5 & 16.8 & 15.5 & 18.2 & 0.29 \\
\hline $\begin{array}{l}\text { Asthma diagnosed by } \\
\text { a doctor }\end{array}$ & 16.8 & 19.6 & 15.7 & 12.7 & 16.7 & 0.05 \\
\hline $\begin{array}{l}\text { Wheezing during or after } \\
\text { exercise }\end{array}$ & 12.8 & 9.2 & 8.6 & 7.8 & 9.4 & 0.002 \\
\hline $\begin{array}{l}\text { Dry night cough unrelated to } \\
\text { cold/chest infection } \\
\text { hinitis }\end{array}$ & 22.8 & 15.4 & 14.8 & 20.4 & 17.4 & 0.010 \\
\hline Rhinitis ever & 20.2 & 19.1 & 25.2 & 38.7 & 24.5 & 0.001 \\
\hline $\begin{array}{l}\text { Rhinitis in the last } \\
12 \text { months }\end{array}$ & 17.6 & 15.7 & 19.9 & 32.6 & 20.3 & 0.001 \\
\hline Burning, itchy, watery eyes & 11.3 & 10.8 & 13.8 & 22.4 & 13.8 & 0.001 \\
\hline \multicolumn{7}{|c|}{ Rhinitis affected daily activities } \\
\hline Not at all & 9.5 & 7.1 & 9.9 & 14.3 & 9.6 & $<0.001$ \\
\hline A little & 5.2 & 5.2 & 7.9 & 12.6 & 7.3 & \\
\hline Moderate & 1.9 & 1.4 & 0.9 & 3.2 & 1.6 & \\
\hline A lot & 1.1 & 1.4 & 1.0 & 2.6 & 1.4 & \\
\hline $\begin{array}{l}\text { Ever had hay fever } \\
\text { czema }\end{array}$ & 14.8 & 19.4 & 28.5 & 40.6 & 25.0 & $<0.001$ \\
\hline Itchy rash ever & 24.5 & 18.7 & 11.3 & 11.7 & 16.3 & $<0.001$ \\
\hline $\begin{array}{l}\text { Itchy rash in the last } \\
12 \text { months }\end{array}$ & 18.4 & 14.5 & 9.2 & 9.7 & 12.8 & $<0.001$ \\
\hline Flexural rash & 18.4 & 14.3 & 8.4 & 8.3 & 12.2 & $<0.001$ \\
\hline \multicolumn{7}{|c|}{ Child awakened by itchy rash in the last 12 months } \\
\hline Not at all & 10.3 & 7.1 & 5.3 & 6.5 & 7.0 & 0.01 \\
\hline$<$ Once/week & 4.7 & 4.4 & 1.4 & 2.1 & 3.1 & \\
\hline >Once/week & 2.9 & 2.7 & 2.5 & 1.1 & 2.4 & \\
\hline Rash cleared completely & 15.2 & 11.2 & 7.2 & 7.3 & 10.0 & 0.008 \\
\hline Eczema ever & 29.3 & 19.1 & 12.8 & 9.3 & 17.3 & $<0.001$ \\
\hline
\end{tabular}

The hygiene hypothesis which posits that exposure to infection in early childhood is protective against allergic diseases has been used to explain the low prevalence of asthma in poor countries where standards of hygiene are low resulting in high exposure to infections. ${ }^{11}$ However, ISAAC phase 3 and several other studies reported high asthma prevalence in low-income countries in Africa and Latin America. ${ }^{1} 1213$ Given the observed increase in asthma prevalence in poor countries, some authors have questioned the ability of the 'hygiene hypothesis' to explain the current trends in asthma prevalence. ${ }^{14}$ Although the aetiology of asthma is still not clearly understood, current evidence suggests complex interac- tions between multiple genes and environmental factors contributing to asthma susceptibility. ${ }^{3} 1516$

Several factors may account for the high prevalence of asthma among Jamaican children. First, there seems to be a high genetic predisposition to asthma evidenced by a high proportion of children with a family history of asthma. Nearly half $(45.5 \%)$ of the children in the sample had a parent with asthma, $50.8 \%$ had a father who had asthma and $44.3 \%$ had a mother with asthma. Parental history of asthma was associated with four times the risk for asthma. While increased risk of asthma among children with a family history of asthma has been reported in several other studies, ${ }^{17-22}$ the proportion of 
Table 4 Weighted prevalence estimates (\%) of asthma and allergy symptoms in 6-7 and 13-14-year-olds

\begin{tabular}{|c|c|c|c|c|c|c|c|c|}
\hline & \multicolumn{4}{|l|}{$6-7$ years } & \multicolumn{4}{|c|}{$13-14$ years } \\
\hline & $\begin{array}{l}\text { Male } \\
(n=138)\end{array}$ & $\begin{array}{l}\text { Female } \\
(n=130)\end{array}$ & $\begin{array}{l}\text { Total } \\
(n=268)\end{array}$ & p Value & $\begin{array}{l}\text { Male } \\
(n=105)\end{array}$ & $\begin{array}{l}\text { Female } \\
(n=107)\end{array}$ & $\begin{array}{l}\text { Total } \\
(n=212)\end{array}$ & p Value \\
\hline \multicolumn{9}{|l|}{ Asthma symptoms } \\
\hline Ever had wheezing & 24.5 & 25.6 & 25.1 & 0.84 & 20.4 & 20.4 & 20.4 & 0.99 \\
\hline $\begin{array}{l}\text { Wheezing in the last } \\
12 \text { months }\end{array}$ & 23.7 & 21.1 & 22.4 & 01.7 & 18.5 & 18.4 & 18.5 & 0.99 \\
\hline \multicolumn{9}{|c|}{ Number of attacks of wheezing in the last 12 months } \\
\hline $1-3$ times & 10.6 & 15.4 & 13.0 & 0.23 & 5.5 & 13.4 & 9.5 & 0.02 \\
\hline $4-12$ times & 10.3 & 4.3 & 7.3 & 0.23 & 13.0 & 3.9 & 8.3 & \\
\hline$>12$ times & 2.6 & 1.3 & 1.9 & 0.23 & 0.0 & 1.1 & 0.5 & \\
\hline \multicolumn{9}{|c|}{ Sleep disturbed by wheezing in the last 12 months } \\
\hline$<$ Once/week & 11.0 & 10.2 & 10.6 & 0.17 & 9.8 & 5.4 & 7.6 & 0.24 \\
\hline >Once/week & 2.1 & 6.4 & 4.2 & 0.13 & 5.3 & 2.8 & 4.0 & 0.67 \\
\hline $\begin{array}{l}\text { Wheezing limited speech } \\
\text { to } 1 \text { or } 2 \text { words }\end{array}$ & 12.5 & 6.4 & 9.4 & 0.28 & 8.7 & 6.0 & 7.3 & 0.71 \\
\hline $\begin{array}{l}\text { Wheezing occurring during } \\
\text { or after exercise }\end{array}$ & 11.3 & 12.0 & 11.6 & 0.76 & 8.6 & 6.8 & 7.7 & 0.84 \\
\hline Ever had asthma & 19.8 & 21.5 & 20.7 & 0.77 & 24.7 & 15.4 & 20.0 & 0.15 \\
\hline Asthma diagnosed by a doctor & 18.8 & 21.5 & 20.2 & 0.39 & 23.7 & 14.9 & 19.2 & 0.23 \\
\hline $\begin{array}{l}\text { Dry cough at night unrelated } \\
\text { to cold/chest infection }\end{array}$ & 15.3 & 20.2 & 17.8 & 0.34 & 21.3 & 14.5 & 17.8 & 0.22 \\
\hline \multicolumn{9}{|l|}{ Rhinitis } \\
\hline Rhinitis ever & 22.4 & 9.5 & 15.9 & 0.003 & 21.6 & 33.0 & 27.4 & 0.12 \\
\hline $\begin{array}{l}\text { Rhinitis in the last } \\
12 \text { months }\end{array}$ & 17.9 & 7.5 & 12.7 & 0.01 & 18.6 & 26.4 & 22.6 & 0.21 \\
\hline \multicolumn{9}{|l|}{ Rhinitis affecting daily activities } \\
\hline Not at all & 10.6 & 1.8 & 6.2 & 0.05 & 6.3 & 17.5 & 12.1 & 0.12 \\
\hline A little & 5.5 & 3.5 & 4.5 & 0.05 & 11.2 & 7.0 & 9.0 & \\
\hline Moderate & 0.5 & 0.8 & 0.7 & 0.05 & 0 & 0.7 & 0.3 & \\
\hline A lot & 0.9 & 1.3 & 1.2 & 0.05 & 1.1 & 0.7 & 0.9 & \\
\hline Ever had hay fever & 25.8 & 12.7 & 19.2 & 0.01 & 28.3 & 46.1 & 37.4 & 0.02 \\
\hline \multicolumn{9}{|l|}{ Eczema } \\
\hline Itchy rash ever & 11.6 & 22.1 & 16.9 & 0.03 & 10.5 & 7.8 & 9.1 & 0.51 \\
\hline $\begin{array}{l}\text { Itchy rash in the last } \\
12 \text { months }\end{array}$ & 6.6 & 17.3 & 11.9 & 0.15 & 9.5 & 7.3 & 8.4 & 0.59 \\
\hline Flexural rash & 6.6 & 16.8 & 11.8 & 0.01 & 9.5 & 5.8 & 7.6 & 0.30 \\
\hline \multicolumn{9}{|c|}{ Child awakened by itchy rash in the last 12 months } \\
\hline Not at all & 2.3 & 7.9 & 5.1 & 0.06 & 5.6 & 4.1 & 4.8 & 0.41 \\
\hline$<$ Once/week & 2.1 & 5.8 & 3.9 & 0.06 & 0 & 1.4 & 0.7 & \\
\hline >Once/week & 2.2 & 2.0 & 2.1 & 0.06 & 3.9 & 1.8 & 2.9 & \\
\hline Rash cleared completely & 6.6 & 12.6 & 9.6 & 0.02 & 6.8 & 6.8 & 6.8 & 0.39 \\
\hline Eczema ever & 18.1 & 19.2 & 18.7 & 0.8 & 12.9 & 6.6 & 9.7 & 0.15 \\
\hline
\end{tabular}

children (almost $50 \%$ ) with a family history of asthma in this study is higher than $12.6 \%$ reported in children from rural and $28.1 \%$ in children from urban areas in Kenya, ${ }^{19} 16 \%$ in Nigerian children ${ }^{20}$ but comparable to $52.8 \%$ in a study involving preschool children in Australia, ${ }^{21}$ and $56.8 \%$ of children involved in a birth cohort evaluating the risk for allergy and asthma in the USA. $^{22}$ While genetic predisposition alone is neither enough nor necessary for asthma to occur, it has been suggested that asthma results from environmental exposures of genetically susceptible individuals. ${ }^{3} 17$

Although allergies are acknowledged as a risk factor for asthma, the role of allergy in asthma has not been clari- fied. ${ }^{23}$ In Jamaican children, the prevalence of current wheeze was significantly higher among children who had rhinitis, hay fever and eczema. Rhinitis in the last 12 months was associated with a sevenfold increase in the risk for asthma. This is in contrast to reports suggesting that asthma in developing countries is non-atopic. ${ }^{24}$

Studies in some Caribbean countries suggest high allergic hypersensitivity among individuals with asthma. ${ }^{25}$ Comorbid allergic rhinitis was reported in $53.9 \%$ of Trinidadian children with severe asthma. ${ }^{26}$ In studies where skin reactivity tests were done, $50 \%-81 \%$ of individuals with asthma showed reactivity to at least one antigen, most commonly house dust mites. Researchers 
Table 5 Weighted prevalence estimates (\%) of asthma symptoms among children with allergies

\begin{tabular}{|c|c|c|c|c|c|c|c|c|}
\hline \multirow[b]{2}{*}{ Asthma symptoms } & \multicolumn{2}{|c|}{ Rhinitis ever } & \multicolumn{2}{|c|}{$\begin{array}{l}\text { Rhinitis in the } \\
\text { last } 12 \text { months }\end{array}$} & \multicolumn{2}{|c|}{ Hay fever ever } & \multicolumn{2}{|c|}{ Eczema ever } \\
\hline & Yes & No & Yes & No & Yes & No & Yes & No \\
\hline Wheezing ever & 44.2 & $14.1^{\star \star \star}$ & 48.6 & $14.1^{\star \star \star}$ & 40.1 & $15.3^{\star \star \star}$ & 37.1 & $18.1^{\star \star \star}$ \\
\hline Wheezing in the last 12 months & 40.9 & $12.6^{\star \star \star}$ & 44.3 & $12.6^{\star \star \star}$ & 36.8 & $13.8^{\star \star \star}$ & 34.1 & $16.4^{\star \star \star}$ \\
\hline \multicolumn{9}{|l|}{ Number of wheezing in the last 12 month } \\
\hline $1-3$ times & 23.5 & $9.3^{\star \star *}$ & 24.9 & $9.3^{\star * *}$ & 22.8 & $9.4^{\star \star \star}$ & 24.4 & $10.2^{\star * *}$ \\
\hline $4-12$ times & 13.4 & $2.9^{* * *}$ & 14.7 & $2.9^{\star \star \star}$ & 11.2 & $3.6^{\star * *}$ & 8.1 & $4.9^{\star * *}$ \\
\hline$>12$ times & 4.0 & $0.4^{\star \star *}$ & 4.7 & $0.4^{\star \star \star}$ & 2.8 & $0.8^{\star \star \star}$ & 1.5 & 1.2 \\
\hline \multicolumn{9}{|c|}{ Sleep disturbance due to wheezing in the last 12 months } \\
\hline 1 night/week & 15.1 & $4.6^{\star \star \star}$ & 15.8 & $4.6^{\star \star \star}$ & 12.5 & $5.4^{\star \star \star}$ & 11.2 & $6.2^{* * *}$ \\
\hline$>1$ night/week & 13.6 & $3.0^{* \star *}$ & 15.1 & $3.0^{* \star *}$ & 12.1 & $3.5^{\star \star \star}$ & 12.6 & $4.1^{* * *}$ \\
\hline Wheezing limits speech to 1 or 2 words & 12.3 & $3.6^{\star * *}$ & 14.4 & $3.6^{\star \star \star}$ & 11.5 & $3.8^{\star * *}$ & 7.2 & 5.2 \\
\hline Asthma ever & 34.2 & $13.0^{\star \star \star}$ & 36.6 & $13.0^{\star \star \star}$ & 29.7 & $14.3^{\star \star \star}$ & 32.8 & $15.2^{\star \star \star}$ \\
\hline Asthma diagnosed by a doctor & 31.1 & $12.0^{\star * \star}$ & 32.9 & $12.0^{\star \star \star}$ & 26.6 & $13.3^{\star \star \star}$ & 29.4 & $14.0^{\star * *}$ \\
\hline Wheezing during or after exercise & 23.1 & $5.0^{\star * \star}$ & 25.9 & $5.5^{\star \star \star}$ & 18.3 & $6.5^{\star \star \star}$ & 17.7 & $7.7^{\star * *}$ \\
\hline $\begin{array}{l}\text { Dry night cough unrelated to cold/chest } \\
\text { infection }\end{array}$ & 41.2 & $9.7^{\star \star \star}$ & 43.8 & $9.7^{\star \star \star}$ & 33.4 & $12.1^{\star \star \star}$ & 29.4 & $14.9^{\star \star \star}$ \\
\hline
\end{tabular}

also reported high densities of house dust mite allergens in mattresses and bedroom dust samples throughout the year due to high temperatures and humidity that are normally found in Caribbean countries. ${ }^{25}$ In Jamaica, Knight-Madden and colleagues ${ }^{27}$ reported skin test reactivity to at least one allergen in $33.8 \%$ of children with asthma. They observed frequent sensitivity to Dermatophagoides farinae, Dermatophagoides pteronyssinus and cockroach allergens among Jamaican children and adults with asthma. Also in this study, the presence of moulds, in the home, was a significant risk factor for current wheeze. This finding is consistent with results of a study in which $82 \%$ of patients with allergic respiratory disease in Jamaica showed reactivity to moulds on skin testing. ${ }^{28}$ This is attributed to the hot and humid climate in the Caribbean that promotes the growth of moulds. ${ }^{25}$ Although studies in some Caribbean countries suggest low sensitivity to cat and $\operatorname{dog}$ dander, $^{24}$ in this study, the presence of cats and dogs in the home was associated with increased risk for current wheeze. Altogether, these findings suggest a role for allergy in asthma in this population.

It has been suggested that a greater portion of allergy symptoms among children in developing countries are due to non-allergic causes such as environmental tobacco smoke. ${ }^{28}$ The prevalence of smoking in this study was $23.3 \%$ and $(20.2 \%)$ of children in this study live with a relative who smokes. In Jamaica, another major source of environmental smoke is open burning of sugarcane fields and other agricultural fields due to slash/burn farming practices, burning garbage and spontaneous combustion of solid waste at dumpsites. ${ }^{29}$

According to the National Environment Planning Agency, in addition to open burning, poor air quality in Jamaica is due to emissions of pollutants from industries, motor vehicles resulting from population growth, a high level of energy use, a growing number of motor vehicles and poor domestic industrial practices. ${ }^{29}$ The National Environment Planning Agency 2010 report identifies sulphur dioxide, nitrogen oxides and particulate matter as major pollutants causing major damage to the environment and human health in Jamaica. ${ }^{29}$ Although the role of such pollutants in the initiation of asthma has not been ascertained, ambient air pollution is associated with exacerbations of existing asthma and deterioration in lung function. ${ }^{30}$ These environmental factors are contributors to the high prevalence of asthma and other respiratory symptoms in susceptible population. ${ }^{31}$

Internationally, higher prevalence of asthma has mainly been reported in urban populations. ${ }^{19} 32 \quad 33$ However, urban/rural differences in asthma prevalence seem to be decreasing. ${ }^{34}$ In this study, there were no significant urban/rural differences in the prevalence of current wheeze $(20.5 \%$ vs $18.5 \%, \mathrm{p}=0.31)$ and doctordiagnosed asthma $(915.4 \%$ vs $18.3 \%, p=0.18)$. Nicolaou and colleagues $^{34}$ suggested that increasing asthma prevalence in rural areas could be due to urbanisation and modernisation of rural environments. These authors also suggested that urban/rural differences in the prevalence of asthma reported in some studies could be due to how urban and rural areas are defined in different settings, differences in types of exposures, cultural practices and lifestyle factors, which present a challenge in comparing data from different settings. ${ }^{34}$ We hypothesised that the lack of significant urban/rural differences in prevalence of current wheeze in this study may in part be due to how urban and rural areas are defined in Jamaica, modernisation of rural environments and exposure to environmental factors some of which emanate from alumina and cement factories, sugar refineries and other industries which are located in rural areas. 2935 
Table 6 Unadjusted OR $(95 \% \mathrm{Cl})$ for risk factors associated with current wheeze

\begin{tabular}{|c|c|c|c|c|}
\hline \multirow[b]{2}{*}{ Risk factor } & \multicolumn{4}{|c|}{ Current wheeze } \\
\hline & Yes (\%) & No (\%) & OR $(95 \% \mathrm{Cl})$ & p Value \\
\hline \multicolumn{5}{|l|}{ Sex } \\
\hline Male & 20.5 & 79.5 & 1.0 & \multirow[t]{2}{*}{0.36} \\
\hline Female & 18.5 & 81.5 & $0.9(0.7$ to 1.1$)$ & \\
\hline \multicolumn{5}{|l|}{ Area of residence } \\
\hline Urban & 18.5 & 81.5 & 1.0 & \multirow[t]{2}{*}{0.4} \\
\hline Rural & 20.5 & 79.5 & $1.1(0.9$ to 1.4$)$ & \\
\hline \multicolumn{5}{|l|}{ Chest infection 1st year } \\
\hline No & 17.8 & 82.2 & 1.0 & \multirow[t]{2}{*}{$<0.001$} \\
\hline Yes & 48.3 & 51.7 & 4.9 (3.0 to 7.9$)$ & \\
\hline \multicolumn{5}{|l|}{ Mother has asthma } \\
\hline No & 17.8 & 82.2 & 1.0 & \multirow[t]{2}{*}{$<0.001$} \\
\hline Yes & 44.3 & 55.7 & 3.6 (2.4 to 5.4$)$ & \\
\hline \multicolumn{5}{|l|}{ Father has asthma } \\
\hline No & 18.9 & 81.1 & 1.0 & \multirow[t]{2}{*}{$<0.001$} \\
\hline Yes & 50.8 & 49.2 & 4.3 (2.4 to 7.9$)$ & \\
\hline \multicolumn{5}{|l|}{ Either parent has asthma } \\
\hline No & 16.8 & 83.2 & 1.0 & \multirow[t]{2}{*}{$<0.001$} \\
\hline Yes & 45.5 & 54.5 & 4.1 (2.8 to 5.8$)$ & \\
\hline \multicolumn{5}{|l|}{ Allergies } \\
\hline \multicolumn{5}{|l|}{ Eczema } \\
\hline Never & 16.4 & 84.6 & 1.0 & \multirow[t]{2}{*}{$<0.001$} \\
\hline Ever & 34.1 & 65.9 & 2.7 (1.9 to 3.7$)$ & \\
\hline \multicolumn{5}{|l|}{ Hay fever } \\
\hline Never & 13.8 & 86.2 & 1.0 & \multirow[t]{2}{*}{$<0.001$} \\
\hline Ever & 36.8 & 64.2 & 3.8 (2.9 to 4.9$)$ & \\
\hline Rhinitis & & & & \\
\hline Never & 12.6 & 87.4 & 1.0 & \\
\hline Ever & 40.9 & 59.1 & 5.0 (3.8 to 6.5$)$ & $<0.001$ \\
\hline Rhinitis in the last 12 months & 44.3 & 55.7 & 5.7 (4.3 to 7.6$)$ & $<0.001$ \\
\hline Breast feeding & & & & \\
\hline $6-12$ months & 18.5 & 81.5 & 1.0 & \\
\hline$>12$ months & 22.3 & 77.8 & 1.3 (0.9 to 1.9$)$ & 0.20 \\
\hline$<6$ months & 22.4 & 77.6 & 1.2 (0.8 to 1.8$)$ & 0.28 \\
\hline Never & 17.7 & 82.4 & 1.0 (0.5 to 1.9$)$ & 0.95 \\
\hline Moulds in the home & & & & \\
\hline No & 23.1 & 76.9 & 1.0 & $<0.01$ \\
\hline Yes & 42.6 & 58.4 & 2.2 (1.2 to 4.3$)$ & \\
\hline Attended day care facility & & & & \\
\hline No & 19.6 & 79.4 & 1.0 & 0.97 \\
\hline Yes & 19.7 & 79.3 & 1.01 (0.8 to 1.3$)$ & \\
\hline Pets in the home at 1st year & & & & \\
\hline Dog & & & & \\
\hline No & 15.7 & 84.3 & 1.0 & 0.02 \\
\hline Yes & 26.3 & 73.7 & 1.7 (1.2 to 2.2$)$ & \\
\hline Cat & & & & \\
\hline No & 15.8 & 84.2 & 1.0 & 0.004 \\
\hline Yes & 29.1 & 71.9 & 1.8 (1.2 to 2.7$)$ & \\
\hline Pets in the home at present & & & & \\
\hline Dog & & & & \\
\hline No & 15.8 & 84.2 & 1.0 & 0.002 \\
\hline Yes & 25.5 & 74.5 & $1.6(1.2$ to 2.1$)$ & \\
\hline Cat & & & & \\
\hline No & 15.8 & 84.2 & 1.0 & $<0.001$ \\
\hline Yes & 32.6 & 67.4 & 2.2 (1.5 to 3.2$)$ & \\
\hline
\end{tabular}


Table 6 Continued

\begin{tabular}{|c|c|c|c|c|}
\hline \multirow[b]{2}{*}{ Risk factor } & \multicolumn{4}{|c|}{ Current wheeze } \\
\hline & Yes (\%) & No (\%) & OR $(95 \% \mathrm{Cl})$ & p Value \\
\hline \multicolumn{5}{|l|}{ Maternal smoking } \\
\hline Not in pregnancy & 19.3 & 80.7 & 1.0 & 0.16 \\
\hline During pregnancy & 27.9 & 70.7 & $1.6(0.8$ to 3.1$)$ & \\
\hline \multicolumn{5}{|l|}{ 1st year of life } \\
\hline No & 19.3 & 80.7 & 1.0 & 0.23 \\
\hline Yes & 26.8 & 73.2 & $1.5(0.8$ to 2.9$)$ & \\
\hline \multicolumn{5}{|c|}{ Smoker in the household } \\
\hline No & 19.3 & 80.7 & 1.0 & 0.77 \\
\hline Yes & 20.2 & 79.8 & $1.1(0.8$ to 1.4$)$ & \\
\hline \multicolumn{5}{|c|}{ Mother's age at birth (years) } \\
\hline$\geq 30$ & 20.0 & 80.0 & 1.0 & \\
\hline $15-19$ & 19.2 & 80.8 & 0.9 (0.6 to 1.5$)$ & 0.83 \\
\hline $20-29$ & 20.3 & 79.7 & $1.0(0.7$ to 1.5$)$ & 0.89 \\
\hline \multicolumn{5}{|l|}{ Birth weight } \\
\hline 2500-3499 & 18.9 & 81.1 & 1.0 & \\
\hline$>2500$ & 23.2 & 77.8 & $1.3(0.8$ to 2.2$)$ & 0.30 \\
\hline$\geq 3500$ & 22.4 & 77.6 & $1.3(0.9$ to 1.9$)$ & 0.23 \\
\hline
\end{tabular}

The age of children included in this study may have contributed to the high prevalence of current wheeze. The study sample included children $<3$ years of age some of whom may have had transient wheeze associated with viral infections. ${ }^{36}$ However, while current wheeze was more prevalent in 2-4-year-olds (27.8\%) compared with older age groups, the prevalence of current wheeze was still high when both the 6-7-year-olds $(22.4 \%)$ and 13-14-year-olds (18.5\%) were examined separately, and respiratory infections during the first year of life were associated with more than four times the risk for asthma (OR 4.83, 95\% CI 3.00 to 7.77). There is also evidence suggesting wheezing in early infancy due to viral infections is a strong predictor of school-age asthma. ${ }^{36}$ The finding that more males than females had higher prevalence of current wheeze and doctor-diagnosed asthma is consistent with findings of other studies which reported sexual dimorphism in the prevalence of asthma in childhood and adolescence related to physiological differences between males and females. ${ }^{37}$

Finally, some authors attributed the increase in the risk of asthma in low- and middle-income countries to urbanisation and adoption of modern lifestyles leading to changes in diet, physical activity and psychosocial stress including violence as well as exposure to indoor and outdoor pollutants, irritants and aeroallergens. ${ }^{38-40}$ Cooper and colleagues ${ }^{38}$ attributed the high prevalence of asthma in Latin America to the processes of urbanisation and adoption of modern lifestyles which has an impact on the environment, living conditions and health status of the population. Jamaica, like many Latin American countries, is also experiencing rapid urbanisation and modernisation related to economic development. ${ }^{35}$ Follow-up studies should examine the relationship between asthma and lifestyle factors such as diet, physical activity as well as obesity and broader social issues such as psychosocial stress including violence, factors that were not examined in this study, which may contribute to high prevalence of asthma symptoms in this population.

\section{Strengths and limitations of the study}

A major strength of this study is the use of an internationally standardised ISAAC questionnaire in a nationally representative sample with a high response rate of $80 \%$, which enabled us to obtain credible prevalence estimates. We used a modified ISAAC protocol in which we sampled from households rather than schools, and within each household, we sampled one child and one adult. This approach enabled us to obtain prevalence estimates for both adults and children in one survey, thereby reducing the cost of such surveys. This approach would be particularly useful in other resource poor countries.

The main limitations of this study is the fact that the prevalence of both asthma and allergies is based on selfreports of symptoms which may have resulted in an overestimate of the actual prevalence. Objective tests for asthma, skin reactivity and tests for $\mathrm{IgE}$ were not done to confirm either asthma or atopy. Another limitation of this study is the fact that caregivers of children younger than 12 years responded to the questionnaire. It has been suggested that prevalence estimates may be influenced by the caregivers understanding of the term 'wheeze', which may result in information bias. ${ }^{41}$ However, in a study involving pre-adolescents, Decker and colleagues ${ }^{42}$ reported agreement in responses between pre-adolescents and their parents for current asthma symptoms. In another study involving adolescents, ${ }^{43}$ self-reports of current asthma symptoms were higher than those reported by parents. Also in this study, the question on 'asthma ever' was modified consistent with terminology used locally. This change was validated locally and when compared with medical records, there was substantial agreement with a $\kappa$ statistic for 'asthma ever' of 0.816 . 
Table 7 Adjusted OR $(95 \% \mathrm{Cl})$ for risk factors associated with current wheeze

\begin{tabular}{|c|c|c|c|c|}
\hline \multirow[b]{2}{*}{ Risk factor } & \multicolumn{4}{|c|}{ Current wheeze } \\
\hline & Yes (\%) & No (\%) & OR $(95 \% \mathrm{Cl})$ & p Value \\
\hline \multicolumn{5}{|l|}{ Chest infections in the 1 st year } \\
\hline No & 17.8 & 82.2 & 1.0 & \multirow[t]{2}{*}{$<0.001$} \\
\hline Yes & 48.3 & 51.7 & 4.8 (3.0 to 7.9$)$ & \\
\hline \multicolumn{5}{|l|}{ Mother has asthma } \\
\hline No & 17.8 & 82.2 & 1.0 & \multirow[t]{2}{*}{$<0.001$} \\
\hline Yes & 44.3 & 55.7 & 3.7 (2.4 to 5.7$)$ & \\
\hline \multicolumn{5}{|l|}{ Father has asthma } \\
\hline No & 18.9 & 81.1 & 1.0 & \multirow[t]{2}{*}{$<0.001$} \\
\hline Yes & 50.8 & 49.2 & 4.5 (2.5 to 8.1$)$ & \\
\hline \multicolumn{5}{|l|}{ Either parent has asthma } \\
\hline No & 16.8 & 83.2 & 1.0 & \multirow[t]{2}{*}{$<0.001$} \\
\hline Yes & 45.5 & 54.5 & $4.2(2.9$ to 6.1$)$ & \\
\hline \multicolumn{5}{|l|}{ Eczema ever } \\
\hline Never & 16.4 & 84.6 & 1.0 & \multirow[t]{2}{*}{$<0.001$} \\
\hline Ever & 34.1 & 65.9 & 2.6 (1.8 to 3.5$)$ & \\
\hline \multicolumn{5}{|l|}{ Allergies } \\
\hline Hay fever & & & & \\
\hline Never & 13.8 & 86.2 & 1.0 & \multirow[t]{2}{*}{$<0.001$} \\
\hline Ever & 36.8 & 64.2 & 4.8 (3.6 to 6.4$)$ & \\
\hline \multicolumn{5}{|l|}{ Rhinitis } \\
\hline Never & 12.6 & 87.4 & 1.0 & \\
\hline Ever & 40.9 & 59.1 & 6.0 (4.6 to 7.9$)$ & $<0.001$ \\
\hline Rhinitis in the last 12 months & 44.3 & 55.7 & 6.9 (5.2 to 9.3$)$ & $<0.001$ \\
\hline \multicolumn{5}{|l|}{ Moulds in the home } \\
\hline No & 23.1 & 76.9 & 1.0 & \multirow[t]{2}{*}{$<0.017$} \\
\hline Yes & 42.6 & 58.4 & 2.3 (1.2 to 4.45$)$ & \\
\hline \multicolumn{5}{|l|}{ Pets in the home } \\
\hline \multicolumn{5}{|l|}{ Dog in 1st year } \\
\hline No & 15.7 & 84.3 & 1.0 & \multirow[t]{2}{*}{$<0.001$} \\
\hline Yes & 26.3 & 73.7 & 1.8 (1.3 to 2.5$)$ & \\
\hline \multicolumn{5}{|l|}{ At present } \\
\hline No & 15.8 & 84.2 & 1.0 & \multirow[t]{2}{*}{$<0.006$} \\
\hline Yes & 25.5 & 74.5 & 1.8 (1.2 to 2.8$)$ & \\
\hline \multicolumn{5}{|l|}{ Cat in 1st year } \\
\hline No & 15.8 & 84.2 & 1.0 & \multirow[t]{2}{*}{$<0.001$} \\
\hline Yes & 29.1 & 71.9 & $2.0(1.4$ to 3.1$)$ & \\
\hline \multicolumn{5}{|l|}{ At present } \\
\hline No & 15.8 & 84.2 & 1.0 & \multirow[t]{2}{*}{$<0.001$} \\
\hline Yes & 32.6 & 67.4 & 2.4 (1.7 to 3.6$)$ & \\
\hline
\end{tabular}

Sensitivity and specificity of the questionnaire for a history of asthma were $93 \%$ and $90 \%$, respectively. Nevertheless, this adjustment may still have yielded an overestimate of the prevalence of this variable. However, prevalence estimates were based on symptoms such as 'wheezing in the last 12 months', which are deemed more accurate and not subject to recall bias. ${ }^{44}$

\section{Conclusions}

The prevalence of asthma and allergies in Jamaican children is high and comparable to that observed in high-income countries. This presents a public health challenge with a potential for high healthcare system costs related to asthma morbidity. Significant risk factors for asthma in this population were a family history of asthma, chest infections in the first year of life, allergies, moulds and pets in the home. A multidisciplinary approach targeting children at high risk for asthma and controlling modifiable risk factors is necessary for prevention and reducing the prevalence and morbidity related to asthma.

Acknowledgements We are grateful to Mrs. Jasneth Mullings for cocoordinating project activities, Dr Beverly Bonaparte, Dr Hermi Hewitt and Dr Laurel Talabere for contributing to proposal development. We also thank the Statistical Institute of Jamaica (STATIN) for organising and carrying out all data collection activities.

Contributors EKK was the principal investigator, EKK, NKW, NOY and YBW contributed to proposal development, EKK, NOY and NKW were responsible for data management and interpretation. EKK, NOY and NCE drafted the original manuscript; all authors reviewed the manuscript and contributed to the intellectual content of the paper. 
Funding The study was supported by the National Health Fund, CHASE Fund and the University of the West Indies. All research was conducted independent of funders.

Competing interests None.

Patient consent Obtained.

Ethics approval Ethics approval was provided by the University Hospital of the West Indies, Faculty of Medical Sciences Ethics Committee and the Ministry of Health Ethics Committee.

Provenance and peer review Not commissioned; externally peer reviewed.

Data sharing statement Additional data on asthma prevalence and management among adults, asthma triggers socioeconomic status is contained in a project report.

\section{REFERENCES}

1. Pearce N, Aït-Khaled N, Beasley R, et al. Worldwide trends in the prevalence of asthma symptoms: phase 111 of the international study of asthma and allergies in childhood (ISAAC). Thorax 2007;62:758-66.

2. Monteil MA, Joseph G, Changit C, et al. Comparison of prevalence and severity of asthma among adolescents in the Caribbean islands of Trinidad and Tobago: results of a nationwide cross-sectional survey. BMC Public Health 2005;5:96.

3. Subbarao P, Mandhane PJ, Sears MR. Asthma: epidemiology, aetiology and risk factors. CMAJ 2009;181:E181-90.

4. Knight-Madden JM, Forrester TS, Lewis NA, et al. Asthma in children with sickle cell disease and its association with acute chest syndrome. Thorax 2005;60:206-10.

5. Lawrence AW, Segree W. The prevalence of allergic diseases in Jamaican adolescents. West Indian Med J 1981;30:86-9.

6. Kahwa EK, Younger NO, Wint YB, et al. The Jamaica asthma and allergies national prevalence survey: rationale and methods. BMC Med Res Methodol 2010;10:29.

7. Kish L. A procedure for objective respondent selection within the household. J Amer Statist Assoc 1949;44:380-7.

8. Weiland SK, Björkstén B, Brunekreef B, et al; International Study of Asthma and Allergies in Childhood Phase II Study Group. Phase II of the international study of asthma and allergies in childhood (ISAAC II): rationale and methods. Eur Respir J 2004;24:406-12.

9. Statistical Institute of Jamaica. Population Census 2001 Country Report. Kingston, Jamaica: The Statistical Institute of Jamaica, 2004.

10. Stata Corporation. Stata Statistical Software: Release 10. College Station, Texas. 2007

11. Martinez FD, Holt PG. Role of microbial burden in the aetiology of allergy and asthma. Lancet 1999;354(Suppl 2):12-15.

12. Ait- Khaled N, Odhiambo J, Pearce N, et al. Prevalence of symptoms of asthma, rhinitis and eczema in 13 to 14 year old children: the International Study of Asthma and Allergies in Childhood Phase III. Allergy 2007;62:247-58.

13. Solé D, Wandalsen GF, Camelo-Nunes IC, et al. Prevalence of asthma symptoms, rhinitis and atopic ecziema among Brazillian children and adolescents identified by the International Study of Asthma and Allergies in Childhood (ISAAC)-Phase 3. J Pediatr (Rio J) 2006;82:341-6.

14. Platts-Mills TA, Erwin E, Heymann $P$, et al. Is the hygiene hypothesis still a viable explanation for the increased prevalence of asthma? Allergy 2005;60(Suppl 79):25-31.

15. Wu T, Boezen HM, Postma DS, et al. Genetic and environmental influences on objective intermediate asthma phenotypes in Dutch twins. Eur Respir J 2010;36:261-8.

16. Yeatts K, Sly P, Shore S, et al. A brief targeted review of susceptibility factors, environmental exposures, asthma incidence and recommendations for future asthma incidence research. Environ Health Perspect 2006;114:634-40.

17. Burke W, Fesinmeyer M, Reed K, et al. Family history as a predictor of asthma risk. Am J Prev Med 2003;24:160-9.

18. Valerio MA, Andreski PM, Scheoni RF, et al. Examining the association between childhood asthma and parent and grandparent asthma status: implications for practice. Clin Pediatr (Phila) 2010;49:535-41.
19. Odhiambo JA, Ng'ang'a LW, Mungai MW, et al. Urban rural differences in questionnaire-derived markers of asthma in Kenyan School children. Eur Respir J 1998;12:1105-12.

20. Abdulrrahman MB, Tagi AM. Childhood bronchial asthma in Northern Nigeria. Clin Allergy 1974;4:171-83.

21. Haby MM, Peat JK, Marks GB, et al. Asthma in preschool children: prevalence and risk factors. Thorax 2001;56:589-95.

22. Cole Johnson C, Ownby DR, Havstad SL, et al. Family history, dust mite exposure in early childhood and risk for pediatric atopy and asthma. J Allergy Clin Immunol 2004;114:105-10.

23. Pearce N, Pekkanen J, Beasley R. How much asthma is really attributable to atopy? Thorax 1999;54:268-72.

24. Castro-Rodriguez JA, Ramirez AM, Touche P, et al. Clinical, functional and epidemiological differences between atopic and non atopic asthmatic children from a tertiary care hospital in a developing country. Ann Allergy Asthma Immunol 2007;98:239-44.

25. Monteil MA. Asthma in English-speaking Caribbean. West Indian Med J 1998;47:125-8.

26. Pinto Pereira LM, Jackman J, Figaro N, et al. Health burden of co-morbid asthma and allergic rhinitis in West Indian children. Allergol Immunopathol (Madr) 2010;38:129-34.

27. Knight-Madden J, Forrester TE, Hambleton IR, et al. Skin test reactivity to aeroallergens in Jamaicans: relationship to asthma. West Indian Med J 2006;55:142-7.

28. Lawrence AW. Clinical aspects of respiratory tract allergic diseases in Jamaica, West Indies. Ann Allergy 1982;49:225-8.

29. National Environment and Planning Agency. State of the Environment Report 2010 Jamaica. http://www.nepa.gov.jm/publications/SOE/ 2010/state-of-The-environment-report-2010-Jamaica.pdf (accessed 23 Apr 2012).

30. Wong GW, von Mutius E, Douwes J, et al. Environmental determinants associated with the development of asthma in childhood. Int J Tuberc Lung Dis 2006;10:242-51.

31. Saha A, Kulkarni $P$, Sayeid H. Living environment and self assessed morbidity: a questionnaire-based survey. BMC Public Health 2007;7:223.

32. Addo-Yobo EO, Woodcock A, Allotey A, et al. Exercise-induced bronchospasm and atopy in Ghana: two surveys ten years apart. PLoS Med 2007:4:e70.

33. Viinanen A, Munhbayarlah S, Zevgee T, et al. Prevalence of asthma, allergic rhinoconjunctivitis and allergic sensitization in Mongolia. Allergy 2005;60:1370-7.

34. Nicolaou N, Sidique N, Custovic A. Allergic disease in urban and rura populations: increasing prevalence with increasing urbanization. Allergy 2005;60:1357-60.

35. Simms D. The Effects of Urbanization on Natural Resources in Jamaica. Planning Institute of Jamaica. 2008. http://pioj.gov.jm/ Portals/0/Social_Sector/Urbanization in Jamaica. PDF (accessed 29 Oct 2011)

36. Martinez FD, Wright AL, Taussing LM, et al. Asthma wheezing in the first six years of life. N Engl J Med 1995;332:133-8.

37. Amqvist C, Worm M, Leynaert B. Impact of gender on asthma in childhood and adolescence: a GA2 LEN review. Allergy 2008;63: 47-57.

38. Cooper PJ, Rodrigues LC, Cruz AA, et al. Asthma in Latin America: a public health challenge and research opportunity. Allergy 2009;64 5-17.

39. Cruz AA, Bateman ED, Bosquet J. The social determinants of asthma. Eur Respir J 2010;35:239-42.

40. Weinberg EG. Urbanization and childhood asthma: an African perspective. J Allergy Clin Immunol 2000;105:224-31.

41. Michel G, Silverman M, Strippoli MP, et al. Parental understanding of wheeze and its impact on asthma prevalence estimates. Eur Respir 2006;28:1124-30.

42. Decker K, Meyer K, Littlefield D, et al. Similar asthma prevalence estimates obtained from preadolescent and parent survey responses. $J$ Clin Epidemiol 2008;61:611-16.

43. Braun-Fahrländer C, Gassner M, Grize L, et al. Comparison of responses to an asthma symptom questionnaire (ISAAC core questions) completed by adolescents and their parents. SCARPOL-Team. Swiss study on childhood allergy and respiratory symptoms with respect to air pollution. Pediatr Pulmonol 1998;25:159-66.

44. Beasley R, Crane J, Lai CK, et al. Prevalence and etiology of asthma. $J$ Allergy Clin Immunol 2000;105:S466-72. 